ГРИЩЕНКО І.В.

канд. екон. наук,

с.н.с. відділу розвитку підприємництвва

Інститут проблем ринку та економіко-екологічних досліджень НАН Украӥни

Франиузький бульвар, 29, м. Одеса, Украйна, 65044

E-mail: irina.v.info@gmail.com

ORCID: 0000-0001-8801-3217

\title{
ПРОКОПЕНКО О.В.
}

д-р екон. наук, професор

професор кафедри економіки

Інноваційний університет Колегіум Мазовія

вул. Соколовська 161, Седльие, Республіка Польща, 08-110

E-mail: prokopenko.olha.w@gmail.com

ORCID: 0000-0003-1362-478X

\section{ДЕСТАБІЛІЗУЮЧИЙ ВПЛИВ ПОМИЛКОВИХ ТА НЕСВОЄЧАСНИХ УПРАВЛІНСЬКИХ РІШЕНЬ НА РОЗВИТОК ПІДПРИЕМНИЦТВА В УКРАЇНІ}

\begin{abstract}
Актуальність. Існує необхідність дослідження впливу прийняття помилкових та несвоєчасних управлінських рішень на розвиток підприємництва в Україні з поєднанням інтересів бізнесу, суспільства та довкілля, як основи удосконалення інструментів організаційно-економічного механізму прийняття управлінських рішень у сфері розвитку підприємництва з урахуванням вимог економічної безпеки України.

Мета та завдання. Метою иъього дослідження є побудова концептуальної моделі впливу помилкових та несвоєчасних управлінських рішень на розвиток підприємництва в Україні. Відповідно до мети дослідження було визначено такі завдання: 1) визначення економічної сутності помилкового та несвоєчасного прийняття рімень у сфері управління підприємницькою діяльністю; 2) дослідити вплив помилкових та несвоєчасних управлінських рішень на розвиток підприємництва в Україні; 3) запропонувати науково-методичний підхід для подолання негативного впливу помилкових та несвоєчасних управлінських рімень на розвиток підприємництва в Украӥні.
\end{abstract}

Результати. Встановлена економічна сутність помилкового та несвоєчасного прийняття управлінських рішень у сфері підприємництва. Ми вважаємо, щзо помилкові та несвоєчасні управлінські рімення - це рімення, які приймаються з порушенням принципів конкретності в часі та економічної ефективності. В статті досліджено вплив помилкового та несвоєчасного прийняття управлінських рішень у сфері підприємництва. Глибина та тривалість дестабілізуючого впливу помилкових та несвоєчасних управлінських рімень у сфері підприємництва визначається головним чином тим, щь вони значно прискорюють основні прочеси, щчо лежать в основі загальної нестабільності сучасної економічної системи. Розглядаючи помилкове та несвоєчасне прийняття рімень у сфері управління підприємниџькою діяльністю, ми можемо виділити вісім основних сфер їх впливу: інституційний напрям, фінансово-економічний напрям, сочіальний напрям, криміналізація економічних відносин, пригнічення інновачій, зовнішні геополітичні впливи, внутрішні геополітичні впливи та структурні економічні дисбаланси розвитку підприємництва. Наявність цих напрямків впливу помилкового та несвоєчасного прийняття рімень у сфері управління підприємництвом призводить до руйнування існуючих та унеможливлює побудову ефективних механізмів інноваційного розвитку підприємництва, викликає деградацію існуючих ресурсів та економічного потенціалу Україна. У статті розроблена концептуальна модель впливу несвоєчасного прийняття рімень у сфері управління національною економікою. У иьому документі запропоновано науково-методичний підхід до подолання негативного впливу помилкового та несвоєчасного прийняття управлінських рішень на збалансований розвиток підприємництва. Цей підхід може трунтуватися на: по-перше, на правильній декомпозиції проблеми - розкладанні проблеми помилкового та несвоєчасного прийняття рішення на кілька основних питань із визначенням їх значущості; подруге, на систематичному опитуванні експертів у цій темі для отримання найбільи точної конкретизачї управлінського рішення, яке може складатися із переліку сторін з їх інтересами та можливостями; крім того - на комп'ютерному моделюванні процесів, щчо відбуваються в соціально-економічних системах. Слід зазначити, щчо одним із найактуальніших питань сьогодні є реалізація такого підходу до прийняття управлінських рімень, який би забезпечив достатньо високий рівень інноваційного розвитку підприємництва, поєднуючи економічні інтереси бізнесу з інтересами суспільства та навколишнього середовища.

Висновки. Результати нашого дослідження дозволили зробити висновок, що помилкове та несвоєчасне прийняття управлінських рішень у сфері підприємництва може призвести не лише до прямого та постійного 
зниження виробничих потужностей, щзо може бути безпосередньо виражено у реальній траті трудового потенціалу. Подолання проблеми помилкового та несвоєчасного прийняття рішень у сфері управління підприємництвом може сприяти формуванню раціональної та збалансованої просторової структури економіки України; до розвитку ефективного конкурентного бізнесу; до раціонального використання трудових ресурсів, вирівнювання сочіально-економічного розвитку України; покращення демографічної ситуації та збільшення тривалості життя населення України; до збільшення валового внутрішнього продукту. Успішна практична реалізація запропонованого науково-методичного підходу щзодо подолання негативного впливу помилкового та несвоєчасного прийняття управлінських рішень можлива лише за умови належного врахування цілей інноваційного розвитку підприємництва та економічної безпеки Украӥни.

Ключові слова: підприсмництво, управлінське рішення, дестабілізуючий вплив, економічна криза, організаційно-економічний механізм, збалансований розвиток.

GRYSHCHENKO I.V.

PhD (Economics), Senior Researcher

Institute of Market Problems and Economic \& Ecological Research of the

National Academy of Sciences of Ukraine

Frantsuzskiy Boulevard, 29, Odesa, Ukraine

E-mail: irina.v.info@gmail.com

ORCID: 0000-0001-8801-3217

PROKOPENKO O.V.

Doctor of Economics, Full Professor.

Adjunct Professor at Economics Department

Collegium Mazovia Innovative University

ul. Sokołowska 161, 08-110 Siedlce, Republic of Poland, 08-110

E-mail: prokopenko.olha.w@gmail.com

ORCID: 0000-0003-1362-478X

\section{DESTABILIZING EFFECTS OF ERRONEOUS AND UNTIMELY MANAGERIAL DECISIONS ON ENTREPRENEURSHIP DEVELOPMENT IN UKRAINE}

Topicality. There is a requirement to study erroneous and untimely adoption of managerial decisions in the field of entrepreneurship in Ukraine combining economic interests of the businesses with the interests of the society and environment as a base to improve the specific tools of the organizational and economic mechanism of managerial decision-making in the field of entrepreneurship development, taking into account the requirements of economic security of Ukraine.

Aim and tasks. The purpose of this research is to build a conceptual model of the impact of erroneous and untimely managerial decisions on entrepreneurship development in Ukraine. Under the purpose of the research, the following tasks were identified: 1) to determine the economic essence of erroneous and untimely decision-making in the field of entrepreneurship management; 2) to investigate the impact of erroneous and untimely managerial decisions on entrepreneurship development in Ukraine; 3) to propose a scientific and methodological approach to overcome the negative impact of erroneous and untimely managerial decisions on entrepreneurship development in Ukraine.

Research results. The economic essence of erroneous and untimely adoption of managerial decisions in the field of entrepreneurship is been established. We consider that erroneous and untimely managerial decisions are decisions which made in violation of the principles of specificity in time and economic efficiency. The impact of erroneous and untimely adoption of managerial decisions in the field of entrepreneurship is investigated in the article. The depth and duration of the destabilizing impact of erroneous and untimely managerial decisions in the sphere of entrepreneurship are determined mainly by the fact that they significantly accelerate the main processes that underlie the general instability of the modern economic system. Considering the erroneous and untimely decision-making in the field of entrepreneurship management, we can identify eight main areas of their impact: the institutional direction, the financial and economic direction, the social direction, the criminalization of economic relations, inhibition of innovation, external geopolitical impacts, internal geopolitical impacts, and structural economic imbalances of entrepreneurship development. The existence of these impact directions of erroneous and untimely decision-making in the field of entrepreneurship management leads to the destruction of existing and makes it impossible to build effective mechanisms for innovative development of the entrepreneurship, causes the degradation of existing resources and economic potential of Ukraine. A conceptual model for the impact of untimely decision-making in a field of national economy management is designed in the article. Scientific and methodical approaches to overcoming the negative impact of erroneous and untimely adoption of managerial decisions on the balanced development of entrepreneurship are been proposed in this document. This approach can be based on: firstly, on the correct decomposition of the problem - decomposition of the problem of erroneous and untimely decision-making into several main issues with the definition of their significance; 
secondly, on a systematic survey of experts in this subject to obtain the most accurate specification of the managerial decision, which may consist of a list of parties with their interests and capabilities; besides - on computer modeling of processes occurring in socio-economic systems. It should be noted, that one of the most pressing issues today is the implementation of such an approach to managerial decision-making, which would ensure a sufficiently high level of innovative development of entrepreneurship, combining economic interests of the businesses with the interests of the society and environment.

Conclusion. The results of our research allowed us to conclude that erroneous and untimely adoption of managerial decisions in the sphere of entrepreneurship can lead not only to a direct and continuous decline in production capacity, which can be directly expressed in the real waste of labor potential. Overcoming the problem of erroneous and untimely decision-making in the field of entrepreneurship management can contribute to the formation of a rational and balanced spatial structure of the Ukrainian economy; to the development of effective competitive businesses; to the rational use of labor resources, equalization of socio-economic development of Ukraine; to the improving the demographic situation and increasing the life expectancy of Ukrainian population; to the increasing of gross domestic product. Successful practical implementation of the proposed scientific and methodological approach to overcoming the negative impact of erroneous and untimely adoption of managerial decisions is possible only if the objectives of innovative development of entrepreneurship and economic security of Ukraine are properly taken into account.

Keywords: entrepreneurship, managerial decision, destabilizing effect, economic crisis, organizational and economic mechanism, balanced development.

Problem statement and its connection with important scientific and practical tasks. The current condition of entrepreneurship management in Ukraine is characterized by disproportion and instability, which are constantly increasing. This phenomenon was especially evident during the recent cyclical crises of the world economy. The aggravation of the economic and socio-political crisis in Ukraine and the World, the intensification of the negative impact on entrepreneurship by both external and internal factors entails the need to rethink and reassess economic efficiency and timeliness of decision-making in the field of entrepreneurship management. Erroneous and untimely economic decisions in the field of entrepreneurship management can cause both immediate acute consequences and consequences that may affect the economic and social development of Ukraine in the long run. In our opinion, the problem of short- and long-term impact of erroneous and untimely economic decision-making in the field of entrepreneurship management is essential for assessing the economic and social prospects of balanced economic development of Ukraine, both now and in the future. Our research, aimed at solving the problem of erroneous and untimely decisionmaking in the field of entrepreneurship management, can contribute to "the development of scientific and technical, socio-economic, socio-political, human potential to ensure Ukraine's competitiveness in the world and sustainable development of society and the state as a whole". This paper is performed in the context of paragraph 1, Art. 3 of the Law of Ukraine of 11.07.2001 № 2623-III "On priority areas of development of science and technology" (Edition of January 16, 2016) [1], "The list of priority thematic areas of research and scientific and technical developments for the period up to 2020", approved by the resolution of the Cabinet of Ministers of Ukraine dated 07.09.2011 № 942 (Edition of September 06, 2016) [2], pp.2, paragraph 3, art. 3 of the Law of Ukraine of June 21, 2018 № 2469-VIII "On National Security of Ukraine" (Edition of March 15, 2020) [3].

Analysis of recent publications on the problem. In studying the problems of managerial decisionmaking in the field of the sphere of entrepreneurship development, was analyzed the scientific results presented in the works of such scientists as Yu. Barabash [4, p. 19-23], who say that "the scientific and methodological foundations of the problem of managerial decisions adoption"; B. Burkynskyi, N. Khumarova, H. Shevchenko et al. [5; 6], study entrepreneurship management in the context of organizational development, in particular, in the field of wellness and recreation; V. Voloshin and O. Deinega [7, p. 185188], which believe that "emphasize the determination of the optimal volume and quality of information, as well as the usefulness of its additional amount"; V. Gavva, and L. Kharikh [8, p. 92-101], which "offer an algorithm for purposeful search for an acceptable option for a business solution using a computer"; V. Dubovoy, and O. Kovaliuk [9, p. 64-68], which "developed a mathematical model that describes the dependence of the state of a linear dynamic system on control solutions and the criterion of stability of the dynamic system in the implementation of the found solution"; O. Oliynychenko [10, p. 79-80], where "analyzed the interpretation of different authors to define the concept of managerial decision" and [11, p. 3842], where "information support is considered as an important component of the process of preparation, adoption and control of managerial decisions" in the sphere of entrepreneurship; N. Mala [12, p. 20-24], where "proposed classification of managerial decisions"; E. Mazur [13, 18-28], where "the pathologies of the state system of regulation by entrepreneurship are determined"; M. Petrushenko, L. Voroshylo et al. [14; 15], 
explore the complex management issues in the context of resolving environmental-economic conflicts; I. Siryk [16], where "methodological approaches to substantiation of managerial decisions are considered", etc.

For example, according to some experts [17, p.22-23] at the center of structural disparities in the entrepreneurship development are primarily "attempts to reform within the old paradigm without a radical change in models of economic development and public administration". In this regard, increasingly erroneous and untimely managerial decisions in the sphere of entrepreneurship can be seen as one of the main factors of the instability of economic relations and management of the national economy in Ukraine.

In this regard, D. Gongalskiy [18, p. 9] says that "whatever reformist zeal, which the government demonstrates, total corruption multiplies the efficiency of all their actions by zero... Economic reforms have proved to be as fake as the fight against corruption. The government continues to solve economic problems by external loans - if given, and if not - by strengthening the fiscal press on the entrepreneurship. Statements about tax cuts and salary increases are nothing more than election rhetoric ..."

At the same time, the author of the work [19, p. 30] convinced that "real GDP ... has declined about $6.7 \%$... this pushes our economy back to 2004-2005 level. The prospects for entrepreneurship development have never been so sad. The industrial production index ... fell by 10.7\%, and in December 2014 - even by $17.9 \%$, approaching the index value of 2009. At the same time, first of all, the damage was inflicted on sectors with a high level of added value".

Some experts $[18$, p. 10] emphasize that "poor countries are highly politically turbulent. Ukraine has already long been among them. And there is no doubt that at the current pace of transformation, both reforms levels and the levels of the reformers themselves, social explosions are only a matter of time".

According to M. Babenko [20, p. 16] "...most experts predict an acceleration of economic growth in Ukraine to only 2.5-3\% ... Against the background of a deep economic downturn in 2014-2015, such a modest dynamic is not enough to ... move from decrease trend to the recovery and further increase in economic indicators..." "... If we create jobs, invest in improving product quality, gain a share of the European market, we will be able to afford growth in wages and prosperity ... we have no choice but to survive all the temporary difficulties and get out of this situation stronger" [21, p.16].

At the same time, M. Zgurovskiy [22, p. 41] notes that "significant changes in this and other pessimistic scenarios can be made by factors that are very difficult to take into account and formalize. This is civil society and system entrepreneurship of Ukraine. Throughout the millennial history of Ukraine, at a time when the nation was under threat, the people organized themselves "from below", took the initiative in their hands, and made radical changes in the course of events that could not be predicted and described by any scenarios".

D. Schneckenberg, V. K. Velamuri, C. Comberg, and P. Spieth [23, p. 405] highlighted that "independent of context, business model innovation creates ambiguity and risks for decision making. Potentially misleading decisions in business model innovation can occur because of cognitive and structural constraints". This seems to confirm the idea that erroneous and untimely managerial decisions may have some destabilizing effects on entrepreneurship development.

Such experts, as I. Constantiou, A. Shollo, M. T. Vendelø [24, p. 51] proposed to "investigated organizational decision making in an organization using state-of-the-art information technologies" and "focused on prioritization meetings where senior managers make decisions regarding project portfolio investments, which are important as they contribute to the organization's innovation strategy". They said, that the findings of their study [24, p. 59] "have important managerial implications. Given the complex and unstructured problems faced by many organizations, intuitive judgement is an unavoidable property of organizational decision making, making up for the shortcomings of analytical tools...".

On the other hand, we can observe that C. Wang, G. Flamini, K. Wang, R. Pei, and C. Chen [25] "study the entrepreneurial decision-making processes and empirically analyze the ways in which social relationships between family members can shape their collective entrepreneurial decision-making behavior".

K. M. Eisenhardt and M. J. Zbaracki [26] suggest "a more realistic view of strategic decision-makers and decision making, and greater attention to normative implications, especially among profit-seeking firms in global contexts".

We can observe that a group of experts, such as Frans N. Stokman, Marcel A.L.M. van Assen, Jelle van der Knoop, Reinier C.H. van Oosten [27] introduce "a methodology for strategic intervention in collective decision making". Their "methodology is based on a decomposition of the problem into a few main controversial issues; systematic interviews of subject area specialists to obtain a specification 
of the decision setting, consisting of a list of stakeholders with their capabilities, positions, and salience on each of the issues; computer simulation".

At the same time, M. J. Haddad and D. A. Sanders [28, p. 180-195] devoted their work to the development of "a new artificial neural network approach to making a business decision". We believe, that such an approach can be used for overcoming the problem of erroneous and untimely decision-making in the field of entrepreneurship management.

Allocation of previously unsolved parts general problem. We believe that from a scientific and practical point of view, the issues of erroneousness and untimeliness of managerial decision-making, and the analysis of their impact on the entrepreneurship development in Ukraine remain insufficiently researched. In our opinion, approaches to the formation of an integrated system of effective and timely decision-making in the field of entrepreneurship management in the context of Ukraine's integration into the European Economic Area are needed further improvement.

Formulation of research objectives (problem statement). The purpose of this research is to build a conceptual model of the impact of erroneous and untimely managerial decisions on entrepreneurship development in Ukraine. Under the purpose of the research, the following tasks were identified: 1) to determine the economic essence of erroneous and untimely decision-making in the field of entrepreneurship management; 2) to investigate the impact of erroneous and untimely managerial decisions on entrepreneurship development in Ukraine; 3) to propose a scientific and methodological approach to overcome the negative impact of erroneous and untimely managerial decisions on entrepreneurship development in Ukraine.

An outline of the main results and their justification. According to the results of our research, we consider that erroneous and untimely managerial decisions are decisions which made in violation of the principles of specificity in time and economic efficiency. Such decisions do not reflect the current state of economic conditions. It can also be decisions that are made without taking into account the socio-economic situation, the operational environment in the country, and without specifying the time of their implementation. The economically efficient managerial decision must be made at the very moment when the operational situation requires it. Thus, the erroneous and untimely adoption of managerial decisions in the field of entrepreneurship we mean the adoption of decisions in this area, which do not meet the principles of economic efficiency and specificity in time. These can be economically inefficient decisions, decisions without specifying a concrete deadline, premature and delayed decisions. Decisions that precede the current needs and objectives of the balance of the socio-economic system usually do not find a basis for their implementation and can lead to the negative trends in entrepreneurship development. Erroneous and delayed decisions can usually contribute to the deepening of negative trends and exacerbate all existing disproportions in entrepreneurship development, exacerbate the course of crisis processes (Fig. 1). The results of our research show that the erroneous and untimely adoption of economic and managerial decisions in the sphere of entrepreneurship is almost always political and cannot be explained only by the internal economic conditions of the reproductive process of the economic system. Significant external debt (Fig. 2), the budget deficit (Fig. 3), and negative foreign trade balance (Fig. 4) in Ukraine are financed by loans in the international debt capital market, which puts strong pressure on the entrepreneurship development.

The long-term impact of erroneous and untimely managerial decisions in the sphere of entrepreneurship is determined by the fact that the results of such decisions can affect over time a large number of reproduction cycles and processes, and thus the economic and social conditions of the entrepreneurship development. The total economic effect that occurs, in this case, leads to long-term changes in the structure of the national economy, and through the mechanism of public debt, part of the negative effect is carried forward to the prospects of the entrepreneurship development.

Diversion of vital raw materials and energy resources for the implementation of erroneous and untimely managerial decisions in the sphere of entrepreneurship is not only extravagance but also a significant economic burden for the entrepreneurship development in Ukraine. The growing shortage of nonrenewable resources is already one of the main problems for our country on the path to balanced entrepreneurship development.

The short-term impact of erroneous and untimely managerial decisions in the sphere of entrepreneurship may be due primarily to such factors as the scale and pace of erroneous and untimely managerial decisions; the volume of parts of income and expenditures directly redistributed as a result of erroneous and untimely managerial decisions to the detriment of the balanced entrepreneurship development; the prevailing, depending on the circumstances, the general socio-economic conditions. 
The depth and duration of the destabilizing impact of erroneous and untimely managerial decisions in the sphere of entrepreneurship are determined mainly by the fact that they significantly accelerate the main processes that underlie the general instability of the modern economic system. These processes are characterized by the following moments.

Firstly, the erroneous and untimely adoption of managerial decisions in the sphere of entrepreneurship reinforces the process of monopolization of the economy and changes the capital structure in favor of oligarchic clans. The erroneous and untimely adoption of managerial decisions in the sphere of entrepreneurship is a crucial cause of inflation, long-term crisis processes in the field of money circulation, and the monetary and financial system. It contributes to the high centralization of money capital in the hands of oligarchic clans, as a result of which the instability of financial and economic relations in Ukraine is deepening.

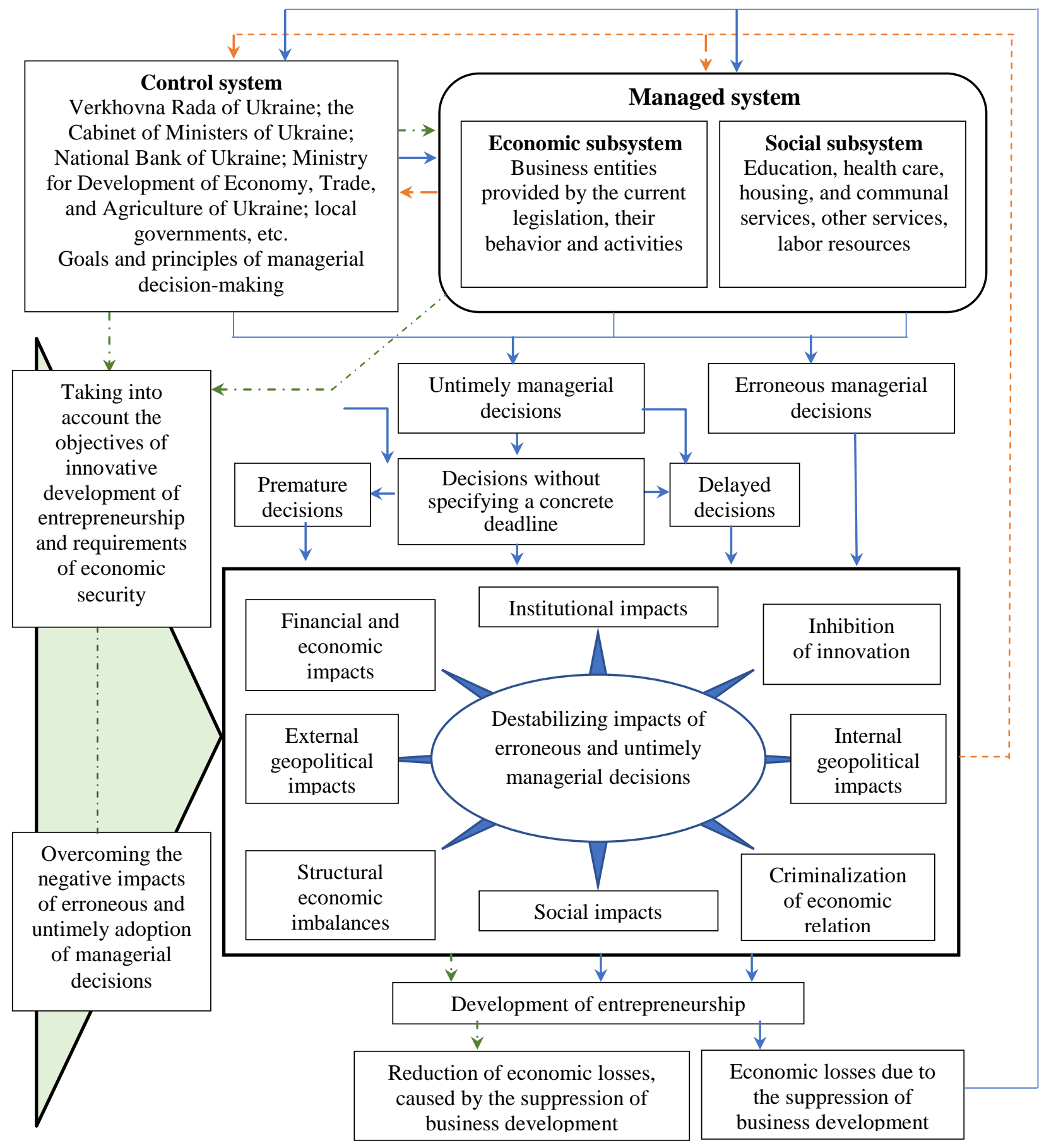

Fig. 1. Destabilizing impact of erroneous and untimely managerial decisions and its overcoming Source: constructed by the authors based on [29-34] 
Secondly, the erroneous and untimely adoption of managerial decisions in the sphere of entrepreneurship and the resulting instability of economic relations are characterized by the growth of a complex of contradictions in the field of oligarchic and state regulation of the economy. This is most manifested in the exacerbation of contradictions between the various economic functions of the state and between certain areas of state regulation of the entrepreneurship. In particular, between the government budget policy of Ukraine, the related problem of public debt and the monetary policy of the National Bank of Ukraine, one of the functions of which should be to control the development of inflation.

Finally, the growing instability of Ukraine's entrepreneurship development as a result of fluctuations and changes in political courses.

Considering the erroneous and untimely decision-making in the field of entrepreneurship management, we can identify eight main areas of their impact: the institutional direction, the financial and economic direction, the social direction, the criminalization of economic relations, inhibition of innovation, external geopolitical impacts, internal geopolitical impacts, and structural economic imbalances of entrepreneurship development.

The institutional direction is the threats that lie in the inefficiency of state management of entrepreneurship and economic relations and processes, the imperfection of national economic legislation, a high level of monopolization of the economy.

The financial and economic direction can consist of such threats, as the import dependence of Ukraine, the irrational structure of exports, the uncontrolled outflow of intellectual and labor resources abroad, high costs of production of goods and services, low quality of domestic products, mass concealment of income and tax evasion.

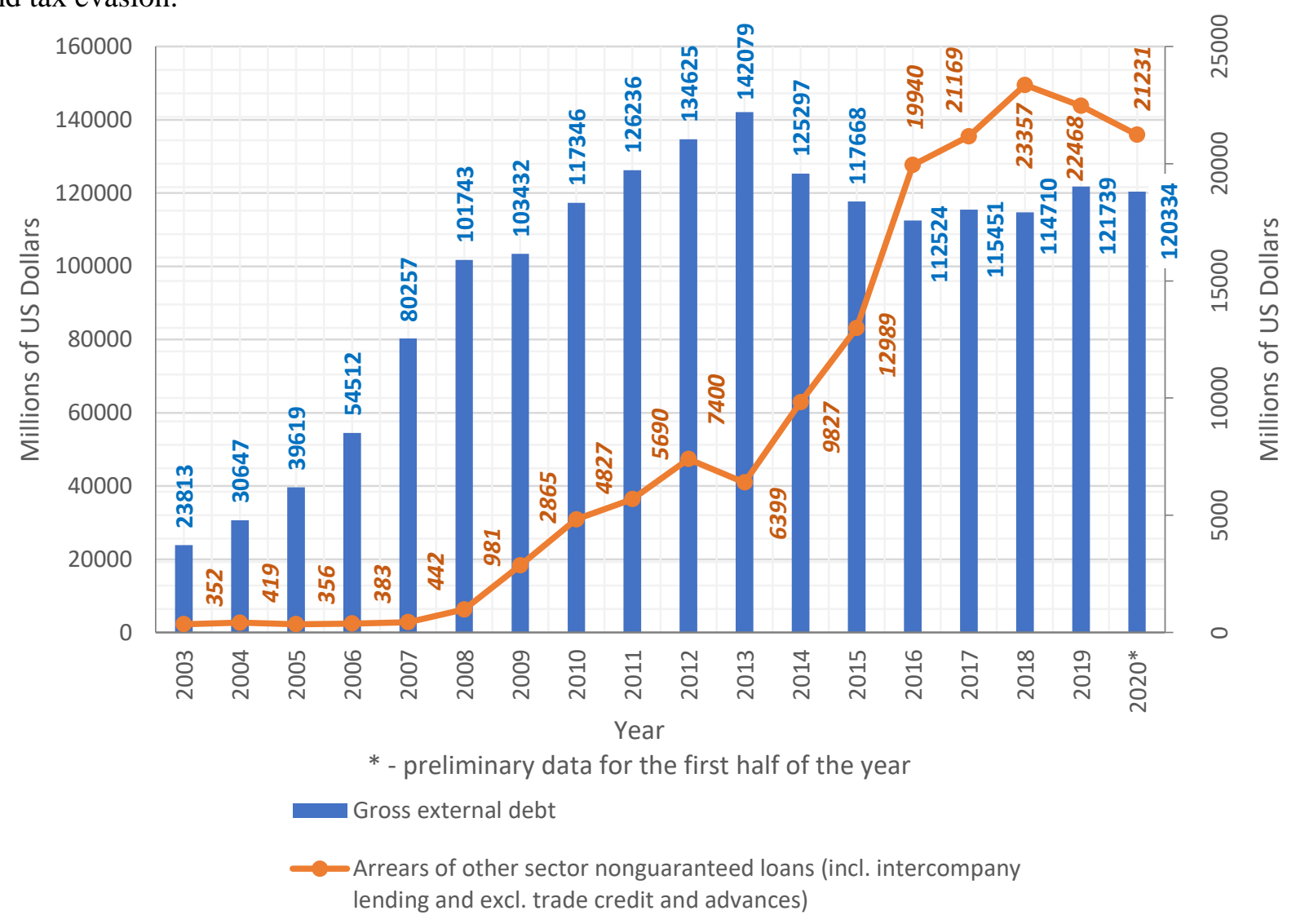

Source: constructed by the authors based on [35]

Fig. 2. External debt in Ukraine

Social direction. First of all, in this area we can distinguish ultra-low labor costs, the constantly increasing level of property stratification of the population, and reducing the solvency of demand for goods and services, increasing poverty and unemployment. This slows down economic development, leads to additional costs in the health care system, deterioration of the quality of human capital, and causes the outflow of labor resources and intellectual capital from Ukraine, leads to the loss of a significant part of scientific and technological potential. 
Criminalization of economic relations. This area includes increasing the level of shadowing of the business and corruption, increasing the scale of organized crime, and its penetration into the basic areas of entrepreneurship, which forms a negative image of the country on the world stage.

The inhibition of innovation. To this area can be assigned loss of a significant part of scientific and technical potential, loss of positions in important areas of scientific and technological progress, low investment activity, and investment mainly in intermediary and financial activities instead of production.

External geopolitical impacts may include military and political instability, regional and local conflicts, interference into the internal affairs from other states, encroachment on state sovereignty and territorial integrity from other states, etc.

To internal geopolitical impacts, we can attribute violation of current legislation by public authorities and local governments, manifestations of separatism, interfaith and interethnic conflicts, imbalance of the political system of society, etc.

Structural economic imbalances of entrepreneurship development, which include the low competitiveness of the national business due to low technological level of domestic products; destruction of the system of reproduction of production potential, reduction of the production sphere, strengthening the focus of raw materials, weak development of transport infrastructure, the deformed structure of production and consumption, as well as the energy crisis.

In periods of favorable economic conditions, the negative impact of erroneous and untimely adoption of managerial decisions in the sphere of entrepreneurship may be hidden, but it still has a negative impact and hinders the balanced development of the entrepreneurship and social sphere.

Particularly clear economic and social consequences of erroneous and untimely adoption of managerial decisions in the sphere of entrepreneurship can be manifested in times of economic crises, as they exacerbate all existing disparities in the country's economy.

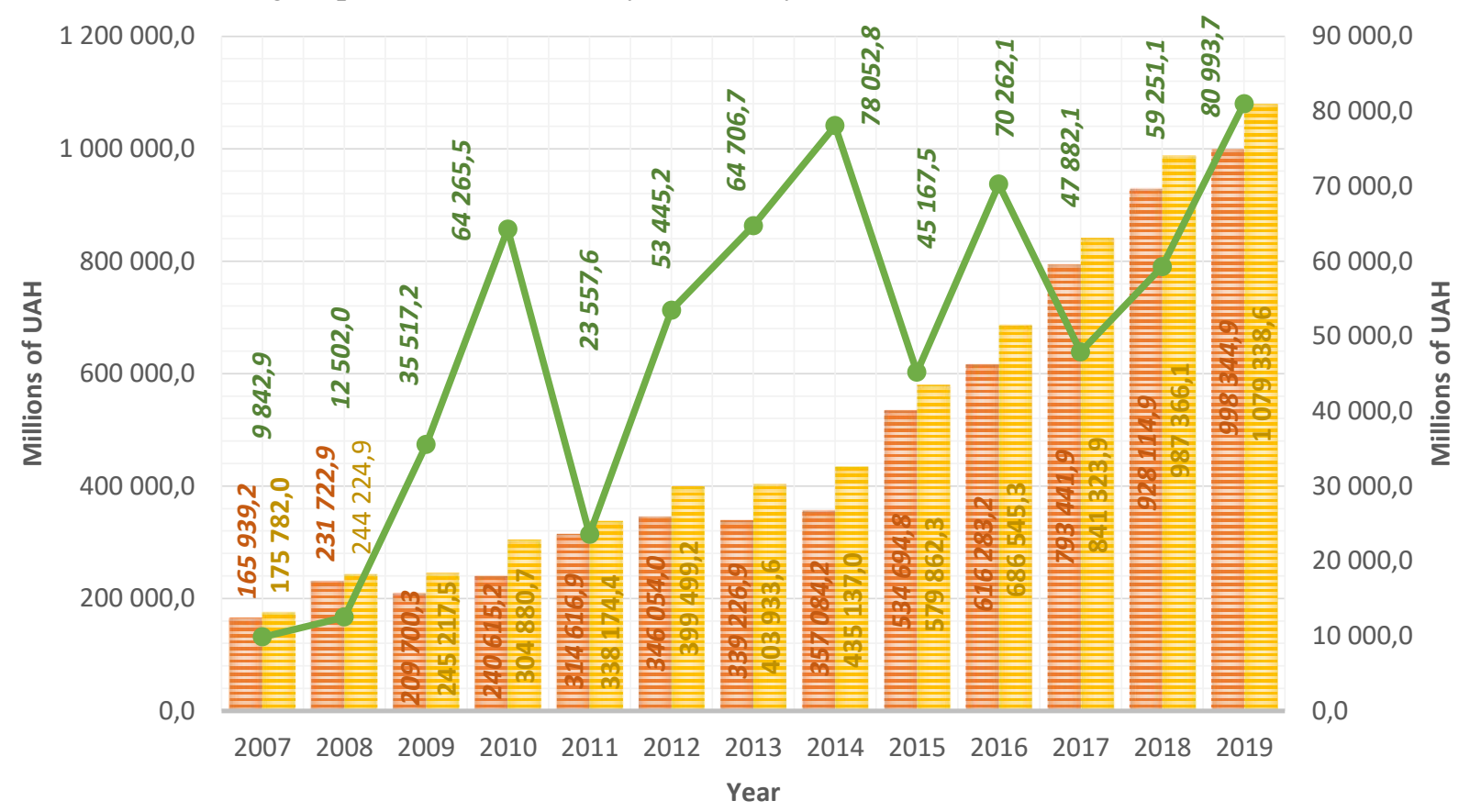

Budget revenues $\rightleftharpoons$ Budget spending $\quad \longrightarrow$ budget deficit

Fig. 3. Budget deficit in Ukraine

Source: constructed by the authors based on [36]

The severity of conflicts caused by erroneous and untimely adoption of managerial decisions in the sphere of entrepreneurship largely depends on the pace of crisis processes in the socio-economic system of the country, their qualitative and quantitative characteristics.

Reducing erroneous and untimely adoption of managerial decisions in the sphere of entrepreneurship could create the preconditions for weakening crisis processes, balanced economic growth, and improving the economic and social well-being of citizens on this basis. But erroneous and untimely adoption of managerial decisions in the sphere of entrepreneurship, which is due mainly to political priorities, exacerbate the crisis. 
The disparities caused by them hinder the balanced development of entrepreneurship and can have a serious negative impact on the well-being of citizens.

The existence of these impact directions of erroneous and untimely decision-making in the field of entrepreneurship management leads to the destruction of existing and makes it impossible to build effective mechanisms for innovative development of the entrepreneurship, causes the degradation of existing resources and economic potential of Ukraine.

These factors are the root cause of additional costs for businesses. They cause the loss of gross domestic product and gross regional product. This necessitates the development of a system of effective economic tools for the innovative development of entrepreneurship.

According to the analysis of research results [26; 27] it can be argued that the scientific and methodological approach to overcoming the negative impact of erroneous and untimely adoption of managerial decisions on the balanced development of entrepreneurship can be based on: firstly, on the correct decomposition of the problem - decomposition of the problem of erroneous and untimely decisionmaking into several main issues with the definition of their significance; secondly, on a systematic survey of experts in this subject to obtain the most accurate specification of the managerial decision, which may consist of a list of parties with their interests and capabilities; besides - on computer modeling of processes occurring in socio-economic systems. The computer modeling of processes occurring in socio-economic systems should include all the basic elements by which the managerial decision-making and implementation of managerial decisions in the field of entrepreneurship take into account the interests and differences in positions of the parties, their significance and existing time limits.

It should be noted, that one of the most pressing issues today is the implementation of such an approach to managerial decision-making, which would ensure a sufficiently high level of the innovative development of entrepreneurship, combining economic interests of the businesses with the interests of the society and environment.

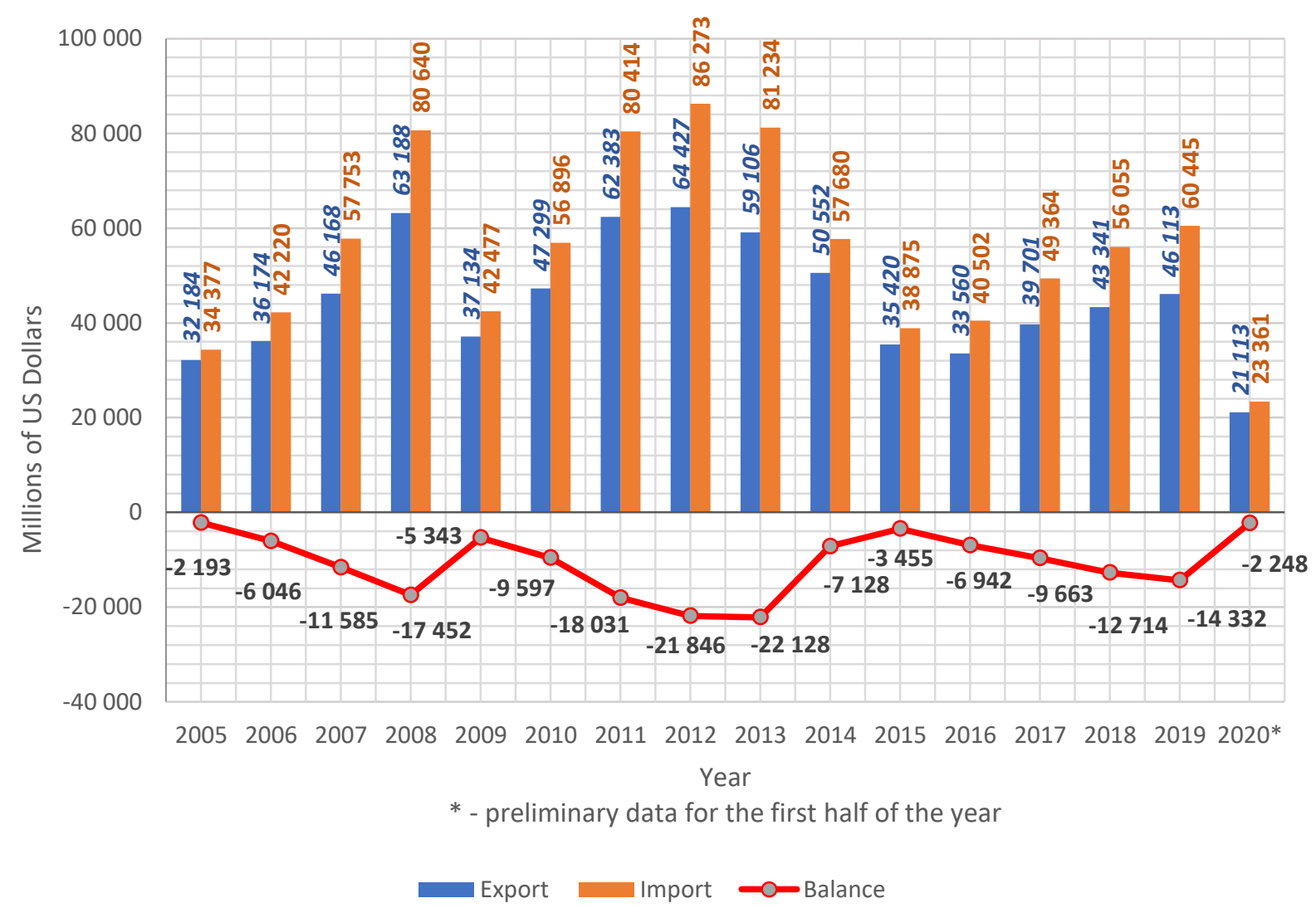

Fig. 4. Foreign trade balance in Ukraine

Source: constructed by the authors based on [37]

Conclusion and perspectives of further research. The results of our research allowed us to conclude that erroneous and untimely adoption of managerial decisions in the sphere of entrepreneurship can lead not only to a direct and continuous decline in production capacity, which can be directly expressed in the real 
waste of labor potential. It should be borne in mind that the negative impact of erroneous and untimely adoption of managerial decisions on the balanced development of entrepreneurship is exacerbated by the fact that the annual deduction of production potential is accompanied by the inefficient use of previously used production capacity.

We believe that the erroneous and untimely adoption of managerial decisions in the sphere of entrepreneurship in Ukraine is becoming a long-term trend and can only lead to further intensification of economic and political instability. The proposed scientific and methodological approach to overcoming the negative impact of erroneous and untimely adoption of managerial decisions on the entrepreneurship development in Ukraine can give an idea of the likely results of overcoming the negative impact of erroneous and untimely decision-making in the sphere of entrepreneurship, the number of parties involved in socioeconomic conflict and stability of the results of the implementation of decisions. Overcoming the problem of erroneous and untimely decision-making in the field of entrepreneurship management can contribute to the formation of a rational and balanced spatial structure of the Ukrainian economy; to the development of effective competitive businesses; to the rational use of labor resources, equalization of socio-economic development of Ukraine; to the improving the demographic situation and increasing the life expectancy of Ukrainian population; to the increasing of gross domestic product.

Successful practical implementation of the proposed scientific and methodological approach to overcoming the negative impact of erroneous and untimely adoption of managerial decisions is possible only if the objectives of innovative development of entrepreneurship and economic security of Ukraine are properly taken into account. This is likely to lead to strategic benefits and overcome the negative impact of erroneous and untimely managerial decision-making, to create the broader political and social support that underpins managerial decision-making in the field of entrepreneurship development, and, as indicated in source [1] to "ensure the competitiveness of Ukraine in the world and sustainable development of society and the state."

Further research in this area will allow improving the specific tools of the organizational and economic mechanism of managerial decision-making in the field of entrepreneurship development, taking into account the requirements of economic security of Ukraine.

\section{ЛІТЕРАТУРА}

1. Про пріоритетні напрями розвитку науки і техніки: Закон України від 11.07.2001р. (редакція від 16.01.2016 р.) № 2623-III / Верховна Рада України. URL: https://zakon.rada.gov.ua/laws/show/262314\#Техt (дата звернення 12.08.2020).

2. Про затвердження переліку пріоритетних тематичних напрямів наукових досліджень i науково-технічних розробок на період до 2020 року: Постанова від 07.09.2011 р. (редакція від 06.09.2016 p.) № 942 / Кабінет Міністрів України. URL: https://zakon.rada.gov.ua/laws/show/942-2011$\%$ D0\%BF\#Text (дата звернення 14.08.2020).

3. Про національну безпеку України: Закон України від 21.06.2018 p. № 2469-VIII (редакція від 15.03.2020 р.) / Верховна Рада України. URL: https://zakon.rada.gov.ua/laws/show/2469-19\#Tехt (дата звернення 19.08.2020).

4. Барабаш Ю. Г. Рішення - заключна ланка в управлінні. / Ю. Г. Барабаш // Науковий вісник Волинського національного університету імені Лесі Українки. - 2009. - №20. - С. 19-23.

5. Шевченко Г. М. Підприємницький менеджмент у контексті організаційного розвитку / Г. М. Шевченко // Вісник Сумського державного університету. Серія Економіка. - 2010. - № 2. - С. 63-72.

6. Shevchenko H. Management of wellness and recreation in urban agglomerations / H. Shevchenko, M. Petrushenko, B. Burkynskyi, N. Khumarova, Y. Opanasiuk // Problems and Perspectives in Management. - 2020. - 18(1). - P. 231-241. https://doi:10.21511/ppm.18(1).2020.20. (дата звернення 14.08.2020)

7. Волошин В. С. Обгрунтування критерію оцінювання корисності інформації при прийнятті управлінського рішення. / В. С. Волошин, О. В. Дейнега // Вісник Хмельницького національного університету. - 2009. - № 6. - Т. 3. - С. 185-188.

8. Гавва В.М. Підготовка господарського рішення за допомогою людино-машинних процедур. / В. М. Гавва, Л. О.Харіх // Економіка та управління підприємствами машинобудівної галузі: проблеми теорії та практики. - 2008. - №2(2). - С. 92-101.

9. Дубовой В.М. Багатокрокові стратегії прийняття рішень у динамічних системах. / В. М. Дубовой, О. О. Ковалюк // Вісник Національного університету «Львівська політехніка». - 2007. - №574. - С. 64-68. 
10. Олійниченко О. М. Аспектний підхід до визначення поняття «управлінське рішення». / О. М. Олійниченко // Наукові праці НУХТ. - 2007. - №21. - С. 79-80.

11. Олійниченко О. М. Інформаційне забезпечення як важлива складова процесу підготовки, прийняття та контролю реалізації управлінського рішення на підприємстві. / О. М. Олійниченко // Економіка харчової промисловості. - 2010. - №3. - С. 38-42.

12. Мала Н. Т. Управлінські рішення: класифікація та процес прийняття. / Н. Т. Мала // Вісник Національного університету "Львівська політехніка". - 2007. - №605. - С.20-24.

13. Мазур Е. Е. Организационные патологии системы государственного регулирования розничной торговли Украины. / Е. Е. Мазур // Экономика Украины. - 2014. - №4(621). - С. 18-28.

14. Петрушенко М. М. Управління еколого-економічними конфліктами в контексті оптимальних механізмів розподілу ресурсів / М. М. Петрушенко, Г. М. Шевченко // Актуальні проблеми економіки. - $2013 . \quad$ - № 3(141). - C. 186-192 URL: https://www.researchgate.net/publication/287596604_Management_of_ecological-

economical_conflicts_within_the_framework_of_the_theory_of_optimal_mechanisms_for_resource_distribu tion. (дата звернення 14.08.2020).

15. Petrushenko M. M. Environmental-economic conflict: conceptual complexity and management issues [Online] / M. M. Petrushenko, L. S. Voroshylo // Economic Processes Management: International Scientific E-Journal. - 2015. - № 3. - Available at: http://epm.fem.sumdu.edu.ua/download /2015_3/2015_3_13.pdf (дата звернення 15.08.2020).

16. Сірік І. П. Методичні підходи до обгрунтування управлінських рішень. / І.П.Сірик // Ефективна економіка. - 2011. - №7. URL: http://www.economy.nayka.com.ua/?op=1\&z=623 (дата звернення 17.08.2020)

17. УКРАЇНА 2030: Доктрина збалансованого розвитку. Видання друге. / О. Жилінська, О. Мельничук, Л. Антонюк, О. Гуменна, А. Радчук, Я. Столярчук, С. Тарута и др. - Львів: Кальварія, 2017. - 164 c. URL: http://econom.chnu.edu.ua/wp-content/uploads/2018/03/E-Book-Doctrine-2030.pdf (дата звернення 10.08.2020). C.8-10.

18. Гонгальский Д. Майданное настроение. / Д. Гонгальский // Личный счет. - 2016. - № 11. -

19. Саливон С. Постиндустриальный синдром. / С. Саливон // Бизнес. - 2015. - №6 (1149). C. 30-33.

20. Бабенко М. Не ждали. / М. Бабенко // Фокус. - 2016. - №51-52 (509). - С. 16.

21. Мазепа И. Взлет падением. / И. Мазепа // Forbes Украина. - 2015. - №3(49). - С. 16.

22. Згуровский М. Сценарии для Украины. / М. Згуровский // Бизнес. - 2015. - № 49 (1192). C. 40-41.

23. Schneckenberg D. Business model innovation and decision making: uncovering mechanisms for coping with uncertainty / D. Schneckenberg, V. K. Velamuri, C. Comberg, P. Spieth // R\&D Management. -
2017.
Vol.
$47 . \quad-\quad$ no.
3. -
P. $\quad 404-419$.
URL: https://www.researchgate.net/profile/Vivek_Velamuri/publication/284726371_Business_model_innovation_ and_decision_making_Uncovering_mechanisms_for_coping_with_uncertainty/links/5dcdede292851c382f3d feee/Business-model-innovation-and-decision-making-Uncovering-mechanisms-for-coping-withuncertainty.pdf (дата звернення 10.08.2020).

24. Constantiou I. Mobilizing intuitive judgement during organizational decision making: When business intelligence is not the only thing that matters / I. Constantiou, A. Shollo, M. T. Vendelø // Decision Support Systems. $\quad$ - 2019. - Vol. 121. - P. 51-61. URL: https://etarjome.com/storage/panel/fileuploads/2019-08-19/1566219652_E12589-e-tarjome.pdf (дата звернення 11.08.2020).

25. Wang, C. Entrepreneurial decision-making and family social capital / C. Wang, G. Flamini, K. Wang, R. Pei, C. Chen // Management Decision. - 2020. - Vol. ahead-of-print. - No. ahead-of-print. https://doi.org/10.1108/MD-10-2019-1414. (дата звернення 12.08.2020).

26. Eisenhardt, K. M. Strategic Decision Making. / Kathleen M. Eisenhardt, Mark J. Zbaracki. // Strategic Management Journal. - 1992. - Vol. 13(S2). - P. 17-37. URL https://doi.org/10.1002/smj.4250130904 (дата звернення 12.08.2020)

27. Stokman F. N., Strategic decision making. / F. N. Stokman, M. A. L. M. V. Assen, J. V. D. Knoop, R. C. H. V. Oosten // Advances in Group Processes. - 2000. - №17. - P. 131-153. https://doi.org/10.1016/S0882-6145(00)17006-7 (дата звернення 10.08.2020). 
28. Haddad, M. J. Artificial Neural Network Approach for Business Decision Making applied to a Corporate Relocation Problem. / M. J. Haddad, D. A. Sanders // Archives of Business Research. - 2020. -

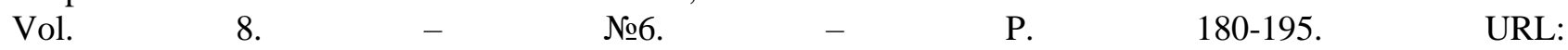
https://researchportal.port.ac.uk/portal/files/21706222/Artificial_neural_network_approach.pdf _дата звернення 14.08.2020).

29. Jones T. Business Economics \& Managerial Decision Making / T. Jones. - John Wiley \& Sons Ltd, $\quad$ England, $2004 . \quad-\quad 502 \quad$ p. $\quad$ URL: http://repository.mut.ac.ke:8080/xmlui/bitstream/handle/123456789/38/Business\%20Economic\%20and\%20 Decision\%20Making\%20(2005).pdf?sequence=1\&isAllowed=y (дата звернення 14.08.2020)

30. Grünig R. Successful decision-making / R. Grünig, R. Kühn // A Systematic Approach to Complex Problems. - Berlin: Springer. - 2005. - 231 p. URL: https://doi.org/10.1007/978-3-642-32307-2 (дата звернення 15.08.2020)

31. Turpin S. M. Decision-making: Theory and practice / S. M. Turpin, M. A. Marais // ORiON. 2004. - Vol. 20. - №. 2. - C. 143-160. https://www.ajol.info/index.php/orion/article/download/34246/6243 (дата звернення 16.08.2020)

32. Петрушенко М. М. Економічні ігри проти природи: модель прийняття рішень у сфері управління екологічними конфліктами. / М. М. Петрушенко // Бізнес Інформ. - 2012. - № 4. - С. 130132.

33. Грищенко В.Ф. Вплив несвоєчасності прийняття рішень у сфері управління національним господарством на економіку України / В. Ф. Грищенко, І. В. Грищенко, Х. Х. Ашхаб // Електронне наукове фахове видання "Економіка та суспільство". - 2018. - Випуск 17. - С. 98-106. DOI: 32782/2524-0072/2018-17-14. - URL: http://www.economyandsociety.in.ua/journal/17_ukr/14.pdf (дата звернення 15.08.2020).

34. Грищенко I.В. Управління експортно-імпортним потенціалом регіону з урахуванням вимог екологічної безпеки як фактор гарантування сталого розвитку / І.В.Грищенко // Інвестиції практика та досвід. - 2012. -№1. - С. 71-74.

35. Валовий зовнішній борг України (за методологією МВФ, КПБ 6) / Національний банк України: офіційне Інтернет-представництво. URL: https://bank.gov.ua/files/ES/ZB_y.xlsx (дата звернення 22.08.2020).

36. Державний бюджет / Національний банк України: офіційне Інтернет-представництво. URL: https://bank.gov.ua/files/macro/C_budget_y.xlsx (дата звернення 23.08.2020).

37. Зовнішня торгівля товарами (відповідно до КПБ 6) / Національний банк України: офіційне Інтернет-представництво. URL: https://bank.gov.ua/files/ES/Tov_y.xlsx (дата звернення 24.08.2020).

\section{REFERENCES}

1. On Priority Branches of Science and Technology Development: The Law of Ukraine on July 11, 2001 (edited on January 16, 2016). no. 2623-III / Verkhovna Rada of Ukraine. Available at: https://zakon.rada.gov.ua/laws/show/2623-14\#Text (accessed August 12, 2020).

2. On approval of the list of priority thematic areas of scientific research and scientific and technical developments for the period until 2020: Decree on September 07, 2011 (edited on September 07, 2016). no. 942 / Cabinet of Ministers of Ukraine. Available at: https://zakon.rada.gov.ua/laws/show/942-2011$\%$ D0\%BF\#Text (accessed August 14, 2020).

3. On National Security of Ukraine: The Law of Ukraine on June 21, 2018. no. 2469-VIII / Verkhovna Rada of Ukraine. Available at: https://zakon.rada.gov.ua/laws/show/2469-19\#Text (accessed August 19, 2020).

4. Barabash Y. G. (2009) Rishennja - zakljuchna lanka v upravlinni [Decision - Final Link in Management]. Scientific Journal of Lesya Ukrainka Eastern European National University. Vol. 20, pp. 1923.

5. Shevchenko, H. M. (2010). Pidpryiemnytskyi menedzhment u konteksti organizatsiinogo rozvytku [Entrepreneurial management in the context of organizational development]. Visnyk Sumskogo derzhavnogo universytetu. Seriia Ekonomika, 2, 63-72 [in Ukrainian].

6. Shevchenko, H., Petrushenko, M., Burkynskyi, B., Khumarova, N., \& Opanasiuk, Y. (2020). Management of wellness and recreation in urban agglomerations. Problems and Perspectives in Management, 18(1), 231-241. https://doi:10.21511/ppm.18(1).2020.20 (дата звернення 14.08.2020).

7. Voloshyn V. S., Dejnegha O. V. (2009) Obgruntuvannja kryteriju ocinjuvannja korysnosti informaciji pry pryjnjatti upravlinsjkogho rishennja. [Substantiation of the criterion of evaluating the 
usefulness of information when making a management decision]. Herald of Khmelnytskyi national university. Economic sciences, Vol. 6, no 3, pp. 185-188.

8. Gavva V.N., Kharikh L.A. (2008) Pidghotovka ghospodarsjkogho rishennja za dopomoghoju ljudyno-mashynnykh procedur [Preparation of economic decision through human-machine procedures]. Economics and management of enterprises in the machine-building industry: problems of theory and practice, Vol. 2(2), pp. 92-101.

9. Dubovoj V.M., Kovaljuk O.O. (2007) Baghatokrokovi strateghiji pryjnjattja rishenj u dynamichnykh systemakh. [Multi-step decision-making strategies in dynamic systems]. Bulletin of the Lviv Polytechnic National University, Vol. 574, pp. 64-68.

10. Olijnychenko O. M. (2007) Aspektnyj pidkhid do vyznachennja ponjattja «upravlinsjke rishennja». [Aspect approach to the definition of "management decision"]. Scientific Works of National University of Food Technologies, no. 21, pp. 79-80.

11. Olijnychenko O. M. (2010) Informacijne zabezpechennja jak vazhlyva skladova procesu pidghotovky, pryjnjattja ta kontrolju realizaciji upravlinsjkogho rishennja na pidpryjemstvi. [Information provision as an important component of the process of preparing, adopting and controlling the implementation of management decisions at the enterprise]. Food Industry Economics, no. 3, pp. 38-42.

12 Mala N. T. (2007) Upravlinsjki rishennja: klasyfikacija ta proces pryjnjattja. [Management decisions: classification and adoption process]. Bulletin of the Lviv Polytechnic National University, Vol. 605, pp. 20-24.

13. Mazur E.E. (2014) Organizatsionnye patologii sistemy gosudarstvennogo regulirovaniya roznichnoy torgovli Ukrainy. [Organizational pathologies of the system of government regulation of the retail trade in Ukraine]. Economy of Ukraine, no. 4 (621), pp. 18-28.

14. Petrushenko, M. M., \& Shevchenko, H. M. (2013). Management of ecological-economic conflicts in the context of the optimal mechanisms theory for the resources allocation. Actual Problems of Economics, 3, 186-192. Available at: https://www.researchgate.net/publication/287596604_Management_of_ecologicaleconomical_conflicts_within_the_framework_of_the_theory_of_optimal_mechanisms_for_resource_distribu tion. (accessed August 14, 2020).

15. Petrushenko, M. M., \& Voroshylo, L. S. (2015). Environmental-economic conflict: conceptual complexity and management issues. Economic Processes Management: International Scientific E-Journal, 3. Available at: http://epm.fem.sumdu.edu.ua/download /2015_3/2015_3_13.pdf. (accessed August 15, 2020).

16. Sirik I. P. (2011) Metodychni pidkhody do obgruntuvannja upravlinsjkykh rishenj [Methodological approaches to the justification of administrative decisions] (electronic journal). Efficient economy, no. 7. Available at: http://www.economy.nayka.com.ua/?op=1\&z=623 (accessed August 17, 2020).

17. Zhylinska O. (ed.) (2017) Ukrajina 2030: Doktryna zbalansovanogho rozvytku [Ukraine 2030. The Doctrine of Sustainable Development], Lviv, Kalvaria. Available at: http://econom.chnu.edu.ua/wpcontent/uploads/2018/03/E-Book-Doctrine-2030.pdf (accessed August 10, 2020).

18. Gongal'skiy D. (2016) Maydannoe nastroenie [Maidan mood]. Personal account, no. 11, p. 8-10.

19. Salivon S. (2015) Postindustrial'nyy sindrom [Postindustrial Syndrome]. Business, no. 6 (1149), pp. 30-33.

20. Babenko M. (2016) Ne zhdali [Did not expect]. Focus, no 51-52 (509), p. 16.

21. Mazepa I. (2015) Vzlet padeniem. [Takeoff by falling]. Forbes Ukraine, no. 3 (49), p. 16.

22. Zgurovskiy M. (2015) Stsenarii dlya Ukrainy. [Scenarios for Ukraine], Business, no. 49 (1192), pp. 40-41.

23. Schneckenberg, D., Velamuri, V. K., Comberg, C., \& Spieth, P. (2017). Business model innovation and decision making: uncovering mechanisms for coping with uncertainty. $R \& D$ Management, 47(3), 404-419. Available

at: https://www.researchgate.net/profile/Vivek_Velamuri/publication/284726371_Business_model_innovation_ and_decision_making_Uncovering_mechanisms_for_coping_with_uncertainty/links/5dcdede292851c382f3d feee/Business-model-innovation-and-decision-making-Uncovering-mechanisms-for-coping-withuncertainty.pdf (accessed August 10, 2020).

24. Constantiou, I., Shollo, A., \& Vendelø, M. T. (2019). Mobilizing intuitive judgement during organizational decision making: When business intelligence is not the only thing that matters. Decision Support Systems, 121, 51-61. Available at: https://e-tarjome.com/storage/panel/fileuploads/2019-0819/1566219652_E12589-e-tarjome.pdf (accessed August 11, 2020). 
25. Wang, C., Flamini, G., Wang, K., Pei, R. and Chen, C. (2020), "Entrepreneurial decision-making and family social capital", Management Decision, Vol. ahead-of-print No. ahead-of-print. Available at: https://doi.org/10.1108/MD-10-2019-1414 (accessed August 12, 2020).

26. Eisenhardt, K. M., \& Zbaracki, M. J. (1992). Strategic decision making. Strategic management journal, 13(S2), 17-37. https://doi.org/10.1002/smj.4250130904 (accessed August 12, 2020).

27. Stokman, F. N., Assen, M. A. L. M. V., Knoop, J. V. D., \& Oosten, R. C. H. V. (2000). Strategic decision making. Advances in Group Processes, 17, 131 - 153. https://doi.org/10.1016/S08826145(00)17006-7 (accessed August 10, 2020).

28. Haddad, M. J., \& Sanders, D. A. (2020). Artificial Neural Network Approach for Business Decision Making applied to a Corporate Relocation Problem. Archives of Business Research, 8(6). 180-195. Available at: https://researchportal.port.ac.uk/portal/files/21706222/Artificial_neural_network_approach.pdf (accessed August 14, 2020).

29. Jones, T. (2004). Business Economics \& Managerial Decision Making. John Wiley \& Sons Ltd, England. Available at: http://repository.mut.ac.ke:8080/xmlui/bitstream/handle/123456789/38/Business\%20Economic\%20and\%20 Decision\%20Making\%20(2005).pdf?sequence=1\&isAllowed=y (accessed August 14, 2020).

30. Grünig, R., \& Kühn, R. (2005). Successful decision-making. A Systematic Approach to Complex Problems. - Berlin: Springer. DOI https://doi.org/10.1007/978-3-642-32307-2 (accessed August 15, 2020)

31. Turpin, S. M., \& Marais, M. A. (2004). Decision-making: Theory and practice. ORiON, 2O(2), 143-160. https://www.ajol.info/index.php/orion/article/download/34246/6243 (accessed August 16, 2020).

32. Petrushenko, M. M. (2012). Ekonomichni ihry proty pryrody: model pryinniattia rishen u sferi upravlinnia ekolohichnymy konfliktamy [Economic games against nature: the model of decision making in the field of environmental conflict management]. Biznes Inform, 4, 130-132 [in Ukrainian]

33. Gryshchenko, V., Gryshchenko, I., \& Ashkhab, H. H. (2018) Vplyv nesvoiechasnosti pryiniattia rishen u sferi upravlinnia natsionalnym hospodarstvom na ekonomiku Ukrainy [The impact of untimely decision-making in a field of national economy management on the economy of Ukraine]. Economy and Society, 17, 98-106. DOI: 32782/2524-0072/2018-17-14. Available at: http://www.economyandsociety.in.ua/journal/17_ukr/14.pdf (accessed August 15, 2020).

34. Gryshchenko, I. (2012) Upravlinnia eksportno-importnym potentsialom rehionu z urakhuvanniam vymoh ekolohichnoi bezpeky yak faktor harantuvannia staloho rozvytku [Management of export-import potential of the region taking into account the requirements of environmental safety as a factor in ensuring of sustainable development]. Investytsiyi: praktyka ta dosvid, Vol. 1, 71-74.

35. National Bank of Ukraine: Official website. (2020) Gross External Debt. Available at: https://bank.gov.ua/files/ES/ZB_y.xlsx (accessed August 22, 2020).

36. National Bank of Ukraine: Official website. (2020) State budget. Available at: https://bank.gov.ua/files/macro/C_budget_y.xlsx (accessed August 23, 2020).

37. National Bank of Ukraine: Official website. (2018) External trade of goods. Available at: https://bank.gov.ua/files/ES/Tov_y.xlsx (accessed August 24, 